Stawomir Zembski

\title{
PRAKTYCZNE MOŻLIWOŚCI WYKORZYSTANIA NAUCZANIE PROBLEMOWEGO W ASPEKCIE DOSOTOSWOANIA DO WYMOGÓW INDUSTRY 4.0
}

\begin{abstract}
Streszczenie: W artykule dokonano analizy przypadku wykorzystania Problem based learning, PBL w aspekcie dostosowywania pracowników do wymogów i oczekiwań Industry 4.0. Czwarta rewolucja przemysłowa jest kolejnym krokiem w kierunku pełnej automatyzacji i robotyzacji czynności dotychczas wykonywanych przez wykwalifikowanych i niewykwalifikowanych pracowników produkcyjnych i administracyjnych. W pracy dokonano analizy przydatności tej metody w szkoleniu pracowników produkcyjnych do potrzeb Industry 4.0. PBL to jedna z wielu technik szkoleniowych prowadzonych poza stanowiskiem pracy, a zwanych $w$ literaturze przedmiotu Off the Job. Zaprezentowana zostanie skuteczność PBL w procesie szkolenia pracowników produkcyjnych oraz przedstawione zostaną zalety dochodzenia do wiedzy za pomocą ciągłego stymulowania procesu kształcenia, za pomocą zadawania pytań i stawiania przed uczestnikami szkolenia wyzwań/problemów.
\end{abstract}

Słowa kluczowe: Wyzwania przemysłu, rewolucje przemysłowe, kompetencje zawodowe, nauczanie problemowe, nauczanie projektowe, samodoskonalenie.

\section{Wprowadzenie}

Współczesna cywilizacja to niespotykane w dziejach ludzkości tempo rozwoju nauki i techniki. Ogromne osiągnięcia w obu tych zakresach powodują, iż praca w nowoczesnym zakładzie produkcyjnym wymaga od pracownika produkcyjnego kwalifikacji, które znacząco wybiegają poza ramy jego dotychczasowego doświadczenia oraz wiedzy nabytej w szkołach [1].

Współczesny przemysł to nowoczesne środowiska oraz inteligentne rozwiązania wymagające od pracownika wiadomości oraz sprawności, które znacząco wynoszą się ponad wąski wycinek jego codziennych czynności i obowiązków. Od pracownika oczekuje się znajomości zasad funkcjonowania i umiejętności płynnego przechodzenia pomiędzy wykonywanymi czynnościami, obsługi różnych maszyn i urządzeń. Płynnego wykorzystywanie dostępnych technologii z zakresu informatyki, robotyki i cyberprzestrzeni.

Obecne zakłady produkcyjne w znaczącej mierze opierają swoją strukturę na tworzeniu wartości dodanej, poprzez efektywne wykorzystanie potencjału ludzkiego i kolejnych rozwiązań technologicznych, dlatego też firmy poważnie

\footnotetext{
${ }^{1}$ mgr, Jeremias Sp. z o.o. z siedzibą w Gnieźnie, s.zembski@wp.pl
} 
podchodzące do tego tematu koncentrują się na posiadanym kapitale ludzkim poddając go sekwencyjnemu i ustawicznemu procesowi szkolenia i doskonalenia jego umiejętności - kształtowaniu jego potencjału [2].

Należy również zauważyć, że pracownik aby stać się konkurencyjnym na obecnym rynku pracy musi zadbać o rozwój swojej wiedzy i kompetencji, które będą miały bezpośredni lub pośredni wpływ na jego karierę zawodową opartą na pracy $\mathrm{w}$ wielu organizacjach $\mathrm{w}$ dobie postępującej globalizacji i dynamicznie zmieniających się rewolucji przemysłowych, które oczekują od pracownika nowych kompetencji zawodowych.

\section{REWOLUCJA PRZEMYSLOWA - INDUSTRY 4.0}

Długo zapowiadana i oczekiwana, nadeszła czwarta rewolucja przemysłowa zgodnie ze słowami, Klaus Schwaba stanęliśmy u progu technologicznej rewolucji, która gruntownie zmienia sposób życia, pracy i naszego współistnienia. W swojej skali, zakresie i kompleksowości stanie się transformacją, której ludzkość dotychczas jeszcze nie doświadczyła [3].

Zanim jednak ona się pojawiła, podwalinę pod pierwszą rewolucje przemysłową położyło wynalezienie maszyny parowej. Koło wprowadzone w ruch siłą pary wodnej popchnęło ludzkość ku nowym odkryciom, możliwością i wyzwaniom. Po 40 latach nowych możliwości pojawiła się Elektryczność, która była fundamentem drugiej rewolucji przemysłowej. Wyprowadziła ludzkość z ciemności do świata, który nie miał już ograniczeń spowodowanych naturalnym cyklem życia, dnia i nocy. Trzeci krok na drodze nie przerwanej rewolucji przemysłowej było pojawienie się nowych rozwiązań $\mathrm{z}$ dziedziny mikroelektroniki, technologii informacyjnych $i$ automatyzacji produkcji. Natomiast czwarta rewolucja przemysłowa, zwana także Industry 4.0, stała się powszechnym wyzwaniem XXI wieku.

Na rysunku 1 przedstawiono rozwój rewolucji przemysłowych na przestrzeni lat.

Istotą czwartej rewolucji jest cyber fizyczna przestrzeń tworzona przez sprzęt, oprogramowanie, sieć i oczywiście ludzi [4]. To właśnie cyber fizyczna przestrzeń stała się podwaliną i główną różnicą pomiędzy poprzednimi rewolucjami. Pozwoliła na zmiany, których dotychczas człowiek nie doznał w żadnej $\mathrm{z}$ opisywanych wcześniej rewolucji. 


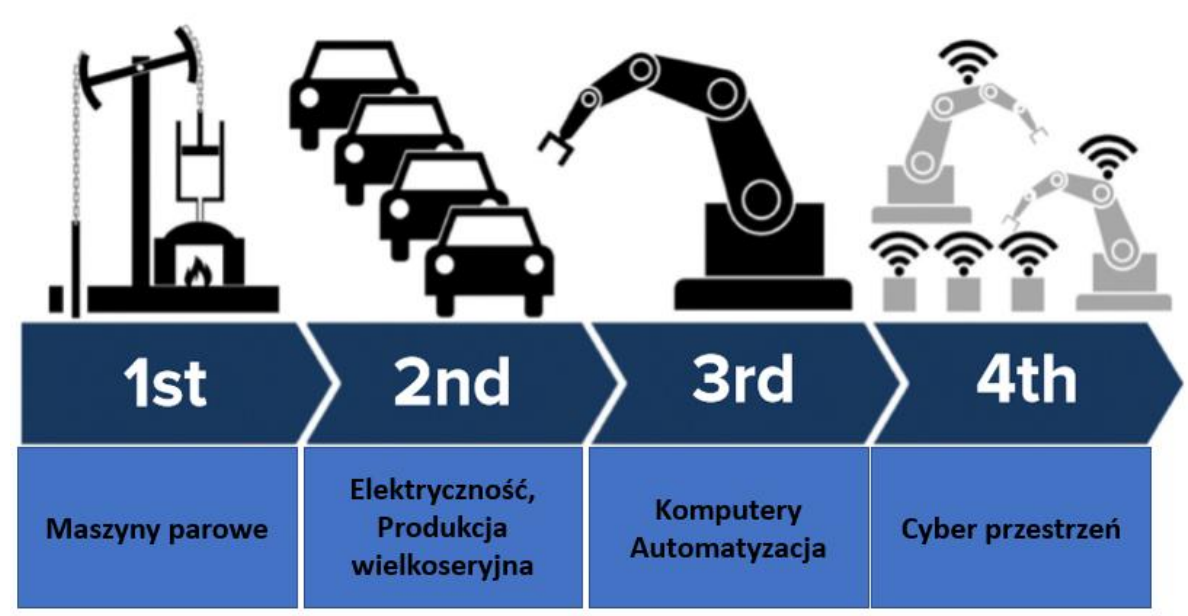

Rys. 1. Rozwój rewolucji przemyslowej

Źródto: By Christoph Roser, http://www.allaboutlean.com (dostęp 4.02.2019)

Koszt danych gwałtownie spadł, stworzenie „chmury” oznacza, że dane są teoretycznie dostępne $\mathrm{w}$ dowolnym miejscu, a rozpowszechnienie komputerów przenośnych, tabletów i smartfonów oznacza, że każdy może uzyskać dostęp do danych. Powszechnie panujące trendy sprawiły, że informacje są praktycznie darmowe i dostępne w czasie rzeczywistym. Co ma istotne znaczenie dla sposobu ich gromadzenia i wykorzystywania. Sieć umożliwiła połączenie praktycznie wszystkich otaczających nas mediów, maszyn i urządzeń [4]

Generowanie, transfer, przetwarzanie i analizowanie dużych zbiorów danych w czasie rzeczywistym - online położyło podwaliny pod nowe interakcje w świecie realnym i wirtualnym. Zmieniło to również bezpośrednio organizację łańcucha wartości w przedsiębiorstwie produkcyjnym. Tempo rozwoju technologicznego doprowadziło do momentu, w którym moc obliczeniowa super komputerów na przestrzeni 18 lat czyli od 2000 roku do 2018 roku wzrosła o ponad 3500\% [5]. W istocie czego potwierdziło się prawo Moore'a' mówiące, że moc obliczeniowa komputerów będzie się podwajać co 2 lata aż do momentu, w którym osiągnie swoje fizyczne ograniczenia [6]. Należy również zwrócić szczególną uwagę na koszty związane $\mathrm{z}$ przechowaniem danych, które zmniejszyły się o około $100 \%$ na przestrzeni ostatnich 17 lat. Wzrost generowanych danych spowodował, że szacuje się że ponad 80\% danych w historii świata powstało w latach 2015-2018 w konsekwencji 
czego wzrosła również ilość urządzeń podłączonych do sieci. W 2020 może ich być ponad 50 miliardów czyli 9 krotnie więcej niż istot ludzkich na ziemi [5].

Nikogo już nie dziwi rozwój sztucznej inteligencji oraz maszyn, które potrafią wykorzystywać algorytmy uczenia się maszynowego w celu przewidywania, podejmowania decyzji lub zapobiegania następstw wywołanych błędnymi decyzjami. Czwarta rewolucja to przestrzeń materialna i niematerialna pozwalająca na rozwój technologii jakie dotychczas były tylko w sferze marzeń, wywodów matematycznych i hipotez naukowców. Rewolucja ta, to autonomiczne samochody, drony i roboty połączone informatyczną siecią. Czat boty komunikujące się z ludźmi zastępując asystentów i opieńków.

Brynjolfsson i McAfee, twierdzą, że tym razem obecna rewolucja przyniesie nam nie tylko automatyzację pracy fizycznej jaką przyniosła trzecia rewolucja przemysłowa ale przede wszystkim „komputery i inne technologie cyfrowe zrobią z pracą naszych mózgów to, co silnik parowy i jego następcy zrobili z pracą naszych mięśni”[7].

Należy zauważyć, że sama łączność i dostępność danych nie spowodował podwyższenia wydajności, ponieważ wbrew pozorom łatwość w dostępie do danych spowodowała przytłoczenie pracowników dużą ilością danych. Pracownicy skupiając się na dużej ilości informacji zaczęli pomijać dane istotne. Przenikający się świat rzeczywisty i wirtualny nawzajem miał i ma znaczący wpływ na procesy produkcyjne i decyzyjne.

Kluczowe dla współczesnych przedsiębiorców, inżynierów, specjalistów i pracowników stało się powiedzenie Alvina Tofflera, że „, Analfabetami XXI wieku nie będą Ci, którzy nie znają Excela lub nie potrafią programować, ale ci, którzy nie potrafią się uczyć nowych rzeczy i odczuwać starych (ang. learn, unlearn and relearn)" [8].

\section{KOMPETENCJE PRACOWNIKÓW W ODNIESIENIU DO INDUSTRY 4.0.}

Rewolucja 4.0 to $\mathrm{w}$ głównej mierze dane generowane, przetwarzane i transferowane pomiędzy maszynami, urządzeniami a człowiekiem, dlatego poszukiwanym specjalistą $\mathrm{w}$ nadchodzących latach będą inżynierowie, technicy z umiejętnościami analizy i zarządzania wygenerowanymi danymi. Poziom współpracy pomiędzy maszyną a człowiekiem osiąga dotychczas niewyobrażalne możliwości. Szacowany jest bardzo dynamiczny wzrost poziomu zatrudnienia specjalistów, który będzie przyspieszał do 2025 roku [5] Jednakże zanim to nastąpi, przemysł musi przygotować bazując na dotychczasowej kadrze pulę koordynatorów, 
wyspecjalizowanych pracowników, którzy będą potrafili wdrażać i zarządzać prostą automatyzacją i robotyzacją procesów produkcyjnych.

Doskonale jest to widoczne $\mathrm{w}$ zakładach produkcyjnych naszych sąsiadów gdzie poziom automatyzacji i robotyzacji jest jednym z najwyższych w Europie [9]. $\mathrm{Na}$ rysunku 2 widoczny jest udział ilości robotów do sumy zatrudnionych pracowników w przemyśle polskim i niemieckim.

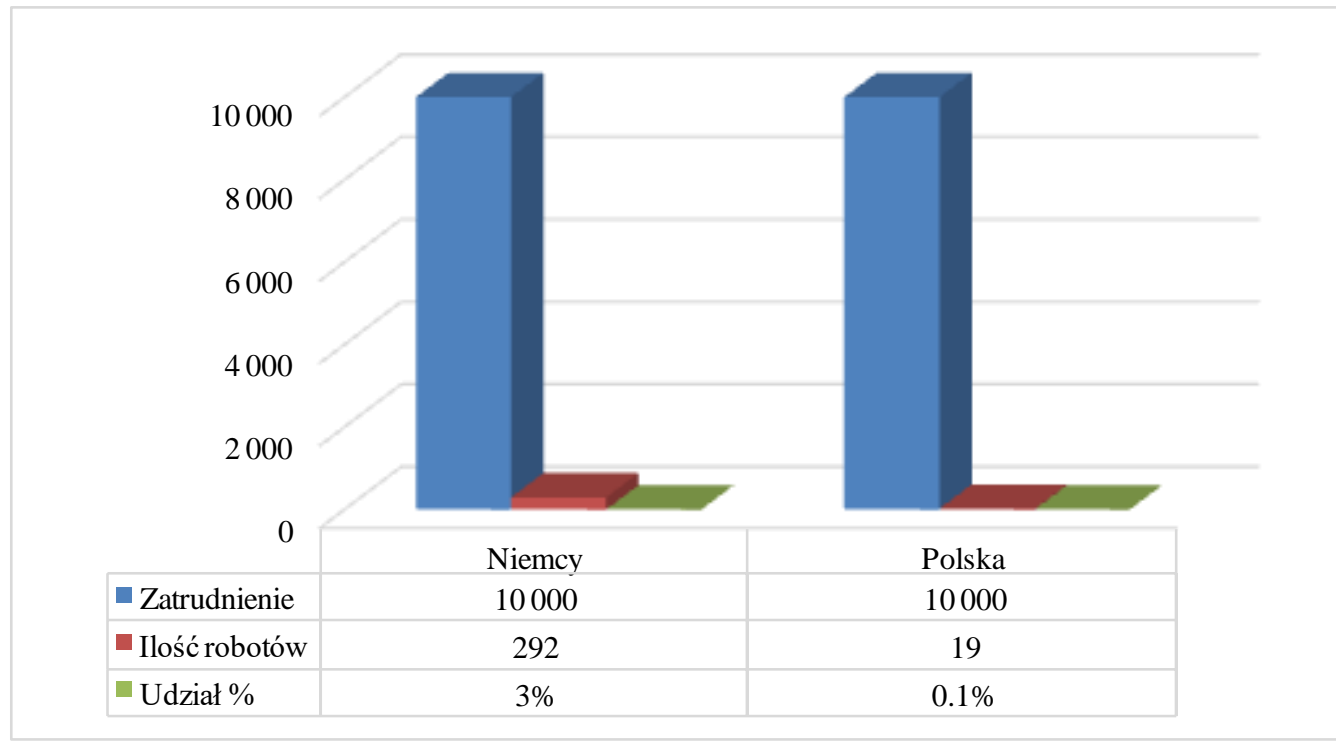

Rys. 2. Liczba robotów przypadających na 10.000 pracowników

Źródto: Opracowanie własne na podstawie: raportu firmy Astor Sp. z o.o./2017

Automatyzacja i robotyzacja, będzie jednym z bodźców, które spowodują dynamiczną potrzebę dopasowywania kompetencji pracowników do nowych wyzwań generowanych przez Industry 4.0. Do wyzwań tych w głównej mierze będą należały[10].

- rozwój pracowników do czynnego uczestniczenia w interakcjach zachodzących pomiędzy człowiekiem a maszyną,

- wykorzystanie wiedzy nabytej we wdrażaniu automatyzacji i robotyzacji $\mathrm{w}$ połączeniu $\mathrm{z}$ cyberprzestrzenią.

Podobne spostrzeżenia formułowane są w raporcie banku światowego, który do wspomnianych powyżej umiejętności dołącza również [11]:

- rozwiązywanie problemów,

- krytyczne myślenie,

- kreatywność, 
- pracę zespołową,

- zarządzanie zespołem,

- inteligencję emocjonalną.

Jack Ma założyciel portalu Alibaba podczas swojego wystąpienia na forum ekonomicznym w Davos w styczniu 2018 roku stwierdził że: „krytyczne myślenie, praca zespołowa, empatia i zajęcia artystyczne to kluczowe kierunki dla edukacji przyszłości” [12].

Jak już wcześniej zostało wspomniane rewolucja 4.0 oraz potencjał jaki ze sobą niesie będzie wymagała od wielu pracowników przekwalifikowania się w trakcie kariery zawodowej. Będzie to możliwe dopiero wtedy kiedy pracownicy i uczestnicy obecnej rewolucji zdadzą sobie sprawę z wagi zaistniałej sytuacji i potrzeby ciągłego doskonalenia swoich umiejętności zawodowych.

Oczywiście ważną rolę w procesie powinno odegrać państwo i szkolnictwo wyższe, które w porozumieniu z przedsiębiorstwami podjęło by konkretne działania mające na celu stworzenie określonych struktur szkoleniowych oraz programu szkolenia, który umożliw przekwalifikowanie obecnych pracowników w taki sposób aby ich dotychczasowe umiejętności oraz kwalifikacje nadążyły za dynamicznie zmieniającymi się oczekiwaniami przedsiębiorstw. Obecne firmy zmuszone sytuacją rynkową opartą na wysokiej konkurencji, presji obniżania kosztów wytworzenia produktu i braku rąk do pracy podążają bardzo dynamicznie w kierunku wdrożenia robotów i automatów, które w ich opinii staną się panaceum na zaistniałą sytuację. Jednakże obecni inżynierowie, specjaliści, technicy i pracownicy szeregowi są znacznie poniżej średniej Organizacji Współpracy Gospodarczej i Rozwoju, jeżeli chodzi o współpracę z nowoczesnymi technologiami [13]. Liderem i wzorem do naśladowania przygotowania pracowników do współpracy $\mathrm{z}$ nowoczesnymi technologiami jest Finlandia, która w wszystkich zakresach wiekowych znacząco góruje na średnią OECD [13].

Z analiz przeprowadzonych przez Organizację Współpracy Gospodarczej i Rozwoju najbardziej w Polsce zagrożeni dynamicznymi zmianami są pracownicy o wykształceniu średnim i podstawowym, którzy tworzą trzon przedsiębiorstw. Ponadto są oni najmniej chętni do pozyskiwania nowych umiejętności i dostosowywania się do nowych wyzwań stawianych przez rynek pracy [13].

Obecne zakłady produkcyjne powinny w znaczącej mierze opierać swoją strukturę na tworzeniu wartości dodanej, poprzez efektywne wykorzystanie potencjału ludzkiego, dlatego też firmy poważnie podchodzące do tego tematu koncentrują się na posiadanym kapitale ludzkim poddając go sekwencyjnemu i ustawicznemu procesowi szkolenia i doskonalenia jego umiejętności - kształtowaniu jego potencjału [14]. Kształcenie ustawiczne (ang. lifelong learning) było i będzie nieodłączny element 
życia i kariery zawodowej każdego z pracowników niezależnie od pełnionej funkcji czy stanowiska.

Kolejnym przełomowym krokiem jak na warunki polskiego rynku pracy będzie zmiana sposobu myślenia, że szkoła średnia lub wyższa są nie wystarczające do zdobycia i piastowania odpowiednich stanowisk zawodowych przez cały okres kariery zawodowej [15].

$\mathrm{Z}$ drugiej zaś strony obecni przedsiębiorcy, właściciele firmy powinni również zmienić sposób myślenia. Zachęcać i stwarzać pracownikom możliwości ustawicznego uczenia się $\mathrm{w}$ trakcie trwania kariery zawodowej (ang. mid-career training) lub też co będzie bardziej oczekiwane i wymagane przez dynamiczne zmiany zachodzące na polskim rynku pracy tworzyć szkolenia w formie krótkich kursów online nazwanych nanodyplomami umożliwiającymi pozyskiwanie niezbędnych umiejętności w skróconej formie dopasowanej do grupy słuchaczy (ang. Skillsfutre) [16].

Nowoczesne środowiska przemysłowe oraz inteligentne rozwiązania będą wymagały od pracownika wiadomości oraz sprawności, które znacząco wynoszą się ponad wąski wycinek ich codziennych czynności i obowiązków. Oczekiwania dotyczące znajomości zasad funkcjonowania i umiejętności płynnego przechodzenia pomiędzy wykonywanymi czynnościami, obsługą różnych maszyn, urządzeń, płynnego zarządzania danymi w cyber świecie staną się codziennością [17].

Odpowiedzią na wyzwania stawiane przez industry 4.0 oraz oczekiwania pracodawców może stać się metoda kształcenia oparta na rozwiązywaniu problemów (ang. Problem Based Learning) stawianych przez środowisko w jakim znajduje się pracownik XXI wieku.

\section{WYKORZSTANIE PBL W DOSTOSOWANIU ZASOBÓW LUDZKICH DO WYMAGAŃ PRZEMYSŁU 4.0}

Podstawą myślenia praktycznego jest działanie a więc wszelkie celowe czynności wewnętrzne i zewnętrzne stanowiące główny sposób sprawdzenia konkluzji, domysłów i pomysłów dotyczących rozwiązania danego zagadnienia. Czynny stosunek do świata, umiejętności radzenia sobie w nowych, trudnych, nieznanych jeszcze sytuacjach, można bardzo mocno wzmocnić, poprzez wdrażanie pracowników do rozwiązywania określonych zadań wynikających $\mathrm{z}$ określonych sytuacji problemowych.

Nauczanie problemowe zdefiniowane zostało jako filozofia nauczania, która opisuje zespół zasad i standardów niezbędnych w procesie efektywnego nauczania 
[18]. Zasady te mogą być modelowane w dowolny sposób w zależności od potrzeb i celów jakie mają być osiągnięte [19].

Metoda nauczania problemowego oparta jest na 5 etapach, krokach do których należą [20]:

- $\quad$ krok 1 - odczucie trudności;

- $\quad$ krok 2 - sformułowanie problemu;

- krok 3 - poszukiwanie rozwiązań, tworzenie hipotez potencjalnych rozwiązań;

- $\quad$ krok 4 - logiczna i jeżeli to możliwe empiryczna weryfikacja hipotez;

- krok 5 - obserwacja wprowadzonych rozwiązań, przyjęcie lub odrzucenie rozwiązania, co w konsekwencji prowadzi do powrotu do kroku trzeciego lub nawet do drugiego.

$\mathrm{Na}$ podstawie obserwacji należy stwierdzić, że nauczanie problemowe umożliwia szybkie przyswajanie wiedzy niezbędnej pracownikowi $\mathrm{w}$ procesie produkcyjnym, ponieważ jest on celowo stawiany przez trenera w sytuacjach, które zmuszają go do myślenia, samodzielnego szukania odpowiedzi, formułowania hipotez, a nie tylko do odtwarzania zakresu teorii, którą przyswoił w czasie wykładu. Formułowanie i uzasadnienie hipotez zmusza uczestnika szkolenia do odwoływania się do posiadanej wiedzy, doświadczeń, przeżyć, czego następstwem jest głębsze utrwalenie nabytej wiedzy i wykształconych umiejętności. Dyskusja nad zgłaszanymi hipotezami wdraża uczestników szkolenia do poprawnego argumentowania swoich założeń i posługiwania się nimi. Pozwala również w sposób nieskrępowany wypowiadać swoje spostrzeżenia, wnioski, przyjmować krytykę i kontrargumentację, która w znaczący sposób przyspiesza proces myślowy.

Kolejną istotną zaletą PBL jest aktywizowanie pracowników średnich i słabych, którzy zazwyczaj podczas prowadzenia standardowych warsztatów tradycyjnymi metodami nikną pośród całej rzeszy uczestników szkolenia, a to w głównej mierze oni tworzą trzon grupy podanej procesowi szkolenia [21].

W procesie wdrożenia i przygotowania pracownika za pomocą nauczania problemowego do wyzwań stawianych przez Industry 4.0 niezbędne są technologie informacyjno-komunikacyjne tworzące cyber przestrzeń, w której pracownik będzie musiał współistnieć wraz z maszynami i innymi urządzeniami multimedialnymi, które staną się podstawą strumienia wartości nowoczesnych przedsiębiorstw produkcyjnych osadzonych w realiach XXI wieku.

Oczekiwania dotyczące efektów uczenia się problemowego wspieranego przez technologie informacyjne są zróżnicowane i należą do nich [22]:

- działanie oparte na myśleniu projektowym, analitycznym,

- zwiększona efektywność przyswajania i wykorzystywania nabytych umiejętności,

- nauczanie skoncentrowane na działaniu ( ang. learning by doing), 
- działania edukacyjne skoncentrowane na uczniach poprzez zastosowanie środowisk pozwalających na głębsza interakcję,

- zwiększone możliwości uczenie się spowodowane efektem dostępu do większej ilości danych i wiedzy.

Obecnie próby wdrożenia PBL wspomaganego przez technologie informacyjne nie są wypełni zadawalające dla wielu uczestników takich projektów [23]. Jednym z powodów może być luka między formalnym nauczaniem wspieranym przez PBL i technologie informacyjne a uczeniem się w miejscu pracy. Nauczanie problemowe odgrywa obecnie jedynie niewielką rolę w uczeniu się w miejscu pracy, normą jest, że około $80 \%$ uczenia się w środowisku pracy jest nieformalne, poprzez naśladownictwo lub podążanie utartymi ścieżkami [24].

Hart J., w swojej książce pt.: Nowoczesne miejsca pracy zwraca szczególną uwagę, na że obecny proces uczenia w erze Industry 4.0 różni się od tradycyjnego uczenia się na wiele sposobów. Jest to proces ciągły, odbywający się na żądanie oraz w krótkich seriach umożliwiających przekazywanie danych w małych porcjach przy zachowaniu krótkich przerw w pracy, które nie mają negatywnego wpływu na zakładaną produktywność [25]. W związku $\mathrm{z}$ dynamicznie postępującą automatyzacją, wdrażaniem autonomicznych systemów i procesem ciągłego monitorowania i kontroli, przyszłe miejsca pracy mają mniejszą lub znikomą potrzebę stałej interakcji człowieka. Ludzie wcześniej monitorujący proces, którego byli częścią stają się osobami odpowiedzialnymi za podtrzymywanie procesu, jego ulepszanie i doskonalenie.

Nowy system pracy Industry 4.0 tworzy „kieszenie czasu” dostępne dla działań takich jak nauka i szkolenie. Te kieszenie czasowe mogą być niemożliwe do zaplanowania $\mathrm{z}$ wyprzedzeniem, więc trudno będzie zsynchronizować działania edukacyjne $\mathrm{z}$ innymi osobami. Oznacza to, że moduły nauczania muszą być przystosowalne, krótkie i możliwe do osiągnięcia bez synchronizacji z pracownikiem wiodącym/nauczycielem. Technika nauczania PBL jest jedną z niewielu technik, która może myć wykorzystywana w tzw. „kieszeniach czasowych”, przyszłych systemów produkcyjnych Industry 4.0.

Prowadzenia pracownika na jego indywidualnej ścieżce odbywa się za pomocą modułów które powinny być [26]:

- krótkie,

- zawierać niezbędną ilość elementów, zagadnień jakie pracownik powinien opanować,

- wykorzystywać dane z jakimi pracownik styka się na co dzień,

- bazować na urządzeniach, maszynach jakie otaczają szkolonego w codziennym życiu produkcyjnym, 
- zawierać w sobie testy i rozwiązania potencjalnych rozwiązań danego problemu/wyzwania.

Doświadczenie pokazuje, że nawet jeśli szkolenie z powodzeniem przenosi nową wiedzę do uczestników, nie ma gwarancji, że zostanie ona zastosowana w pełnym zakresie [27]. Dlatego też trenerzy powinni czynnie uczestniczyć w procesie rozwiązywania problemu, być współczesnymi Sokratesami Industry 4.0. Nie podsuwać rozwiązań ale szeregiem pytań i sugestii ukierunkowywać pracowników na określone drogi prowadzące do osiągnięcia zadanego celu. Równie istotną rolę jak trenerzy $\mathrm{w}$ procesie kształcenia problemowego odgrywają również menadżerowie, którzy powinni wspierać procesy zmian $\mathrm{w}$ swojej firmie, identyfikować obszary, które powinny być ulepszone, wspólnie z pracownikami inicjować projekty.

Według Kirkpatrick, istnieją cztery poziomy oceny sukcesu uczenia się, nabywania wiedzy [28], które z powodzeniem można zastosować do oceny nauczania problemowego w procesie dokształcania do Industry 4.0. Należą do nich:

- Reakcja, co oznacza uczucia uczestników szkolenia i po szkoleniu;

- Uczenie się, które odzwierciedla faktyczną poprawę wiedzy uczestnika;

- Zachowanie, które ocenia, czy uczestnicy faktycznie zmieniają coś lepiej w swoim prawdziwym życiu zawodowym;

- Wyniki, które próbują podsumować wpływ szkolenia na wyniki biznesowe.

Istotnym, jak nie najważniejszym skutkiem opisywanej metody jest przygotowanie pracowników, do prowadzenia systematycznej i planowanej obserwacji, ciągłego uczenia się i dostrzegania związków, zależności miedzy rzeczami, zjawiskami i procesami zachodzącymi $\mathrm{w}$ procesie produkcyjnym. Umiejętności w ten sposób nabyte, mogą wykorzystywać do przewidywania następstw postępowań lub też do zrozumienia nowych zjawisk i procesów, jakie zachodzą w zakładach produkcyjnych XXI wieku [29]. Tak zdobyta wiedza, staje się narzędziem przydatnym $\mathrm{w}$ przekształceniu otaczającej go rzeczywistości, w jakiej na co dzień się znajduje i pracuje. Rozwiązywanie problemów w drodze czynności myślowych, sprawdzanych następnie za pomocą czynności praktycznych przyczynia się również znacząco do uświadomienia pracownikowi celowości podjętych działań i wysiłku, jaki musiał ponieść wraz z grupą, aby wykreować, stworzyć hipotezy, które stały się potencjalnymi rozwiązaniami. Ukierunkowuje i uczy go jak odpowiednio ogniskować uwagę na problemach zasadniczych.

Zaprezentowana metoda działania oraz sposób jej wdrożenia w rozwoju pracowników produkcyjnych w odróżnieniu od innych metod szkoleniowych przyczynia się w ogromnej mierze do wyrobienia wśród szkolonych osób nawyku samokształcenia [30]. Jest to bezcenna umiejętność, która wyrobiona w pracownikach 
pozwala na dostrzeganie i rozwiązywanie problemów oraz sprawdzania uzyskanych rezultatów. Przyzwyczaja do samodzielności działania i posługiwania się właściwymi technikami w procesie codziennego doskonalenia zawodowego. PBL jest efektywnym podejściem do nauczania i uczenia się szczególnie, gdy weźmie się pod uwagę długość przechowywania wiedzy i umiejętność jej stosowania w codziennych czynnościach [30]. Pozwala na szybkie wdrożenie pracownika do procesu, który wykazując się dużym zaangażowaniem podczas rozwiązywania problemu, osiąga wyższe wyniki, niż uczestnicy szkoleń wdrażanych tradycyjnymi metodami [31].

\section{PODSUMOWANIE}

Przemysł wytwórczy zmienia się obecnie z produkcji masowej na produkcję dostosowaną do indywidualnych potrzeb, co skutkuje wyzwaniami dotyczącymi różnych aspektów produkcji, takich jak: wydajności, elastyczności, jakości.

Zadania w zakresie inżynierii i zarządzania operacjami w dobie Industry 4.0 wymagają od pracowników, techników, inżynierów więcej umiejętności multidyscyplinarnych pozwalających na obsługę, zarządzanie i funkcjonowanie w erze maszyn i urządzeń połączonych cyberprzestrzenią.

Współpraca ludzi i inteligentnych maszyn wyzwala wzajemną potrzebę uczenia się - redefiniowanie ról zawodowych. To co wcześniej było wykonywane przez człowieka obecnie może być równie dobrze wykonane lub lepiej przez autonomicznego robota, autobota lub autonomiczny system komputerowy. Podczas tej stopniowej zmiany, niektóre stanowiska pracy znikną, a niektóre zostaną na nowo utworzone.

Głównym powodem zatrzymania rozwoju obecnych pracowników jest mała wiedza lub jej brak na temat bieżącego procesu produkcyjnego - Industry 4.0. Szkoły oraz pracodawcy nie nadążyli za nadchodzącymi zmianami, czego wynikiem jest brak wykwalifikowanej kadry produkcyjnej i inżynieryjnej. Powoduje to szybkie tworzenie i wprowadzanie nowych zmian do programów nauczania oraz kursów doskonalących przystosowujących do dynamicznych przeobrażeń zachodzących w środowisku produkcyjnym.

Odpowiedzią na szybko kroczące zmiany niesione przez Industry 4.0. staje się nauczanie problemowe, które odpowiednio ukierunkowane i umiejscowione w środowisku pracy pracownika oraz otaczającej go cyber przestrzeni, pozwoli na jego szybkie przekwalifikowanie, dokształcenie i przystosowanie do potrzeb pracodawcy. 
Ważną cechą nauczania problemowego w dobie industrializacji XXI wieku jest również możliwość szczegółowego zaplanowania, opomiarowania i szybkiego wdrożenia.

Pracownicy rozwijani, dokształcani za pomocą PBL nie poznają jak stosować udogodnienia technologiczne niesione przez industry 4.0. ale uczą się, jak wybrać odpowiednie technologie i jak wdrożyć podejście branżowe $4.0 \mathrm{w}$ swojej fabryce, miejscu pracy. Dzięki temu nie stają się odtwórcami naśladowcami danego standardu pracy ale stają się twórcami, nowych rozwiązań bazujących na maszynach, urządzaniach i cyberprzetrzeni.

Należy pamiętać, że maszyna bez zasilania była niewystarczająca w pierwszej rewolucji, Komputer bez Internetu i człowieka nie był konkurencyjny w trzeciej rewolucji, dlatego też ważne jest, aby uznać, że przedsiębiorstwa muszą optymalizować sprzęt, oprogramowanie a przede wszystkim dokształcać ludzi, którzy z nich korzystają, ponieważ to oni mają ten świat zmieniać i to dla nich ten świat się zmienia.

\section{Literatura}

[1.] Trocki M.: Nowoczesne zarządzanie projektami. Polskie Wydawnictwo Ekonomiczne. Warszawa 2013.

[2.] Makuch M.: Wspótczesny rynek pracy. Zatrudnienie i bezrobocie w XXI wieku. Uniwersytet Wrocławski, 2014.

[3.] Schwab K.: World Economic Forum 2016.

[4.] Baldassari P., Roux J.D.: Industry 4.0: Preparing for the Future of Work. Copyright of People \& Strategy 2018.

[5.] Zielewski P., Putra M., Marciniak T.: Ramię w ramię z robotem. Forbs 2017.

[6.] G.E. Moore, https://www.computerhistory.org/siliconengine/moores-law-predicts-thefuture-of-integrated-circuits/ (odczyt 14.01.2019).

[7.] Brynjolfsson E., McAfee A.: The second machine age: Work, progress, and prosperity in a time of brilliant technology, W. Norton \& Company, 2014

[8.] Tofler A.: Trzecia fala, Państwowy Instytut Wydawniczy 1986. Państwowy Instytut Wydawniczy, Warszawa 1985.

[9.] Raport Astor 2017, https://www.astor.com.pl/blog/2016/10/raport-przemysl-4-0polskich-fabrykach, (odczyt 14.01.2019).

[10.] McKinsey Global Institute Jobs lost, jobs gained: Workforce transitions in a time of automation. listopad 2017. 
[11.] World Development report 2016, http://www.worldbank.org/content/dam/World bank/Publications/WDR/WDR\%202016/WDR2016_overview_presentation.pdf, (odczyt 14.01.2019).

[12.] Jack M.: Ma, World Economic Forum, 2018.

[13.] Organisation for Economic Co-operation and Development, Skills Matter: Further Results from the Survey of Adult Skills, OECD Skills Studies 2016.

[14.] Malinowski M.: Potencjat ludzki a efektywność ekonomiczna przedsiębiorstw wykorzystanie metod taksonomicznych $w$ ujęciu regionalnym. Uniwersytet Przyrodniczy w Poznaniu.

[15.] Prauzner T.: Technologie informacyjne - wybrane problemy spoleczne. Wydawnictwo Edukacja - Technika - Informatyka 2011.

[16.] Brown A., Bimrose J., Barnes S., Hughes D.: Journal of Vocational Behavior, Volume 80, Issue 3, June 2012.

[17.] Makuch M.: Rozważania o pracy z perspektywy współczesnego społeczeństwa. Ujęcie psychologiczno-społeczne, Uniwersytet Wrocławski, Wrocław 2014.

[18.] Graff E., Kolmos S.: Management of change implementation of problem based and project- based learning in engineering. Netherlands 2007.

[19.] Kolmos A.: Research on PBL practise in engineering education, Sense Publishers Rotterdam p.: 9-21, 2008.

[20.] Dahms M. L.: Problem based Learning in Engineering Education, Attracting Young people to Engineering: p.:10-21, 2014.

[21.] Sadeh I., Ziohn M.: The development dynamic Inquiry Performance within an open inquiry settings, Journal of research in science Teaching 46, p. 1137-1160, 2009.

[22.] Pouezevera S. D.: Planning and evaluating ICT in education programs using four dimensions of sustainability. International Journal of Education and development using ICT, 2014.

[23.] Kinchin I.: Avoiding technology-enhanced non learning. British journal of Education Technology 43, 2012.

[24.] Cross J.: Where did 80\% come from? Informal learning Blog.,2011.

[25.] Hart J.: Rethinking Workplace Learning, Center for Learning \& Performance Technologies, 2016.

[26.] Sultana R.G.: Learning Career management skills in Europe. A critical review. Journal of Education and Work, 2012.

[27.] Schallock B., Rybski C., Jochem R., Kohl H.: Learning Factory for Industry 4.0 to provide future skills beyond technical Skills, 2018

[28.] Kirkpatrick J.D., Kirkpatrick K.: Four Levels of Training Evaluation, ATD Press Alexandria, USA 2017. 
[29.] Kim M., Tan A.: New vision and challenges in inquiry - based curriculum change in Singapore. International Journal of Sciences Education, 35 289-311.

[30.] Yew E., Chng E.: Schmidt H. Is learning in problem-based learning cumulative?. Adv Health Sci Educ 2011;

[31.] Pease M.A., Kuhn D.: Experimental Analysis of the Effective Components of Problem-Based Learning, Science Education 95(1):57 - 86 · January 2011.

\title{
PRACTICAL POSSIBILITY OF USING PROBLEM BASED LEARNIG TO THE REQUIREMENTS AND EXPECTATIONS OF INDUSTRY 4.0
}

\begin{abstract}
The article analyzes the case of the use of Problem based learning, PBL in the aspect of adapting employees to the requirements and expectations of Industry 4.0. The fourth industrial revolution is the next step towards full automation and robotization of activities previously performed by qualified and unqualified production and administrative employees. The work analyzes the usefulness of this method in training production workers to the needs of Industry 4.0. PBL is one of many training techniques conducted outside of the workplace and called in the literature Off the Job. The effectiveness of PBL in the training process in the production workers will be presented, also the advantages of reaching knowledge through the continuous stimulation of the education process will be presented by asking questions and putting challenges / problems before the participants of the training.
\end{abstract}

Key word: Industry challenges, Industry revolution, professional competences, problem based learning, project learning, self-improvement.

Data przestania publikacji do Redakcji: 16.04.2019

Data akceptacji publikacji przez Redakcję: 29.05.2019

DOI: 10.30657/qpi.2019.10.03 